\title{
Morphological and Biochemical Characterization of Bacteria Associated with the Developmental Stage of the Peach Fruit Fly, Bactrocera zonata (Diptera: Tephritidae)
}

\author{
Naiyar Naaz $^{1 *}$, Jaipal S. Choudhary ${ }^{2}$, Ashok Choudhary ${ }^{1}$ and Abhijit Dutta ${ }^{3}$ \\ ${ }^{1}$ University Department of Botany, ${ }^{3}$ University Department of Zoology, Ranchi University, \\ Morabadi, Ranchi-843008, (Jharkhand) India \\ ${ }^{2}$ ICAR-RCER, Farming Systems Research Centre for Hill and Plateau Region, Plandu, \\ Ranchi-834010 (Jharkhand) India. \\ *Corresponding author
}

\section{A B S T R A C T}

\section{Keywords}

Bactrocera zonata, Developmental stages, Bacterial symbionts, Enterobacteriaceae

Article Info

Accepted:

12 September 2020 Available Online: 10 October 2020
Bacterial-insects associations are very common, can be parasitic to mutualistic and reside in the gut, hemocoel and body cells of insects, which play an important role in their nutrition, digestion and development. The aim of present study was to morphological and biochemical characterization of the bacteria isolated from the different developmental stages of the peach fruit fly, Bactrocera zonata. The total 35 bacterial colonies on the basis of colony morphology were screened belongs to various genera different family, including rods of both gram-positive as well as gram-negative and only few gram positive coccus and rod-coccus. Out of total bacterial isolates, thirteen different bacterial species belonging to eleven genera (seven families) were identified from the developmental stage (first Instar larvae, third Instar larvae, pupa, male and female adults) of Bactrocera zonata. The bacteria species viz., Klebsiella pneumonia, Klebsiella oxytoca, Enterobacter cloacae, Enterobacter sp., Providencia sp., Pantoea sp., Citrobacter freundii, Pseudomonas sp., Enterococcus sp., Ochrobactrum sp., Bacillus sp., Microbacterium sp., and Rhodococcus sp. were identified to be associated with different life stages. Genera Klebsiella, Enterobacter and Pseudomonas of family, Enterobacteriaceae were found in all the development stages. Therefore, the present study significantly supplements to the available information on the cultivable bacterial diversity associated with the developmental stages of B. zonata.

\section{Introduction}

Bacterial-insects associations including both intracellular and intercellular are very common in nature and known since the last century (Petri, 1909). Associations between them are close and complex ranging from parasitism to mutualism, with a long period of association and co-evolution history (Dillon and Dillon 2004; Dale and Moran, 2006). The bacterial communities in insects mostly reside in the gut, mycetomes, hemocoel and within the cells. The associated bacteria plays an important role in host's nutrition, digestion, 
protection, detoxification of insecticides, resistance to pathogens, and semiochemicals production (Dillon and Dillon 2004; Russell and Moran 2006; Oliver et al., 2003; Engel and Moran 2013; Feldhaar, 2011; Douglas, 2015; Hammer and Bowers 2015; Ezenwa et al., 2012; Wingfield et al., 2016; Hosokawa et al., 2017). The bacterial community associated with the insects is likely to be influenced by various factors such as diet and the host on which insects feed (Ferrari et al., 2007; Hosokawa et al., 2017; Wagner et al., 2015; Medina et al., 2011). The variations in the bacterial communities have been reported at different stages of insects' development (Aharon et al., 2013; Malacrinò et al., 2018).

The Tephritid (Dipteran : Tephritidae) fly are commonly known as "fruit flies". The peach fruit fly, Bactrocera zonata (Saunders.) is a polyphgous pests, which is a menace to more than 50 species of fruit crops and wild plants (Duyck et al., 2004) particularly in South Asia (including India), Southeast Asia and some parts of Africa (Kapoor, 1993, CABI/EPPO 2013). B. zonata is considered as one of the most destructive fruit pests species of peach (Prunus persica (L.) Batsch), guava (Psidium guajava L.), mango (Mangifera indica L.) in tropical and subtropical climatic countries (Choudhary et al., 2015). Instead of enormous damage potential of $B$. zonata, the studies have been limited to its biology, distributions and population genetic structure (Duyck et al., 2004; Choudhary et al., 2015; Choudhary et al., 2018).

To the best of our knowledge, very few studies have been carried out to access the bacterial communities associated with $B$. zonata adult flies using culture-dependent techniques (Reddy et al., 2014; Naaz et al., 2016) and culture-independent techniques across ontogeny (Naaz et al., 2020). However, there are no previous reports on the characterization of the cultivable gut bacterial communities associated with the $B$. zonata across different developmental stages. The present study was undertaken to isolate and morphologically as well as biochemically characterize the dominant bacteria associated with the different developmental stages $B$. zonata. This information will act as baseline for subsequent studies such as roles of these microorganisms in their development and management.

\section{Materials and Methods}

\section{Sample collection and rearing}

Fruit flies infested wood apple (Aegle marmelos L.) fruits were collected from Research farm of ICAR Research Complex for Eastern Region, Research Centre (ICARRCER, RC), Ranchi, India ( $23^{\circ} 45^{\prime} \mathrm{N}$ latitude, $85^{\circ} 30^{\prime}$ E longitude, elevation $620 \mathrm{~m}$ AMSL) in May, 2018. Subsequent rearing (up to 6 generations) was carried out in the laboratory at ambient room conditions $\left(25 \pm 1^{\circ} \mathrm{C}\right.$ temperature; $65 \pm 5 \%$ RH; $12: 12$ h LD photoperiod). The infested fruits were kept individually in $20 \times 15 \mathrm{~cm}$ cage with $5 \mathrm{~cm}$ of thick sterile fine sand until emergence of the adults. The adults pair (male and female) of B. zonata was released into a smaller rearing cage $(30 \times 30 \times 30 \mathrm{~cm})$ provided with their natural host (Bael) for oviposition. The feeding was supplemented with adult diet [(glucose and protein hydrolyzate (Protinex ${ }^{\circledR}$, Pfizer Ltd., India) in the ratio of 1:1 in Petri plates)] and water ad-libitum through soaked cotton swabs in a $50 \mathrm{ml}$ beaker. The food supplements were replaced weekly. After oviposition, the $1^{\text {st }}$ instar larvae were directly collected by cutting the infested fruits of wood apple with fruit fly. Different stages of B. zonata were reared on same host fruits in the laboratory conditions according to protocol described by Choudhary et al., (2020) and collected for further experiments. Larvae that emerged from the fruits and 
moved out to the sand for pupation were collected for $3^{\text {rd }}$ instar larval stage. A fair number of $3^{\text {rd }}$ instar larvae were left in the soil to pupate in order to obtain pupal stage samples and other pupae were left for the emergence of adult stage. Five days old adult male and females were collected to study the microbiota associated with the adult stage.

\section{Dissection and isolation of bacteria}

The bacteria were isolated from gut of first instar larvae and third instar larvae, mid-aged pupae (whole-body) and 5-day-old male and female adults of $B$. zonata, following the protocol described by Liu et al., (2016). Before being dissected, adults were anaesthetized at $-18^{\circ} \mathrm{C}$ for $5 \mathrm{~min}$. Samples (larvae, pupae and adults) were washed with ethanol $(75 \%)$ for $30 \mathrm{~s}$, followed by sodium hypochlorite $(1 \%)$ for one minute and finally rinsed with sterilized water for three times to remove surface contamination. Five individuals of larvae, five male and five female flies were dissected aseptically in a petri dish under a stereoscope, and then all the dissected tissues and five pupae were placed in a $1.5 \mathrm{~mL}$ centrifuge tube containing $400 \mu \mathrm{L}$ of sterile water, respectively. The tissue suspension was blended under a laminar air flow hood. There were three biological replications for each treatment. To isolate the cultivable gut bacteria, the blended samples were diluted with four concentrations $\left(10^{-1}\right.$, $\left.10^{-2}, 10^{-3}, 10^{-4}\right)$. One hundred microliters of diluent was separately spread onto PYEA (Peptone yeast extract agar) and NA (Nutrient Agar) medium and incubated at $37 \pm 1^{\circ} \mathrm{C}$ for 24-48 h for bacterial growth. Single colony of each of the bacterial isolates was separated with the inoculation loop and streaked onto respective PYEA and NA plates for their growth. Predominant bacterial isolates were obtained through repeated sub-culturing to ensure their purity. The purified bacterial isolates with respective medium were maintained on PYEA slants and/or plates at 4$8^{\circ} \mathrm{C}$ for further use.

\section{Morphological and biochemical characterization of gut bacteria}

Morphological (Shape, Gram's staining), cultural (Pigment production, growth in broth medium) and biochemical (citrate, methyl red, Voges-Proskauer (V.P.), triple sugar iron (TSI), catalase, oxidase and carbohydrate fermentation tests) characterization of the pure culture was done by standard techniques and isolates characteristics were compared with Bergey's Manual of Determinative Bacteriology (Holt et al., 2000).

\section{Results and Discussion}

Isolation of bacterial isolates associated with the developmental stage of the peach fruit fly, Bactrocera zonata

Bacteria associated with the different developmental stage (First Instar larvae, Third Instar larvae, Pupa, male and female Adult) of the peach fruit fly, Bactrocera zonata were isolated on two culture media viz. Peptone Yeast Extract agar (PYEA) and nutrient agar (NA) media (enriched culture media). It was found that bacteria were associated with all the developmental stage of the B. zonata. A total of 35 different bacterial colonies were observed on two different enriched culture media (Table 1).

\section{Morphological characterization}

The bacterial isolates isolated from the different developmental stages of $B$. zonata were mostly rod shaped except two bacterial isolates namely BL1G and B13D were coccus and BM5 was Rod-coccus shaped isolated from larval stage and male adult flies. All the bacterial isolated were Gram-negative but few isolates such as BL1E and BL1G in first 
instar larvae, BL3B and BL3H in third instar larvae, BM4 and BM5 in male adult flies and only BF5 in female adult flies were Grampositive in nature (Table 2). Most of the isolates were found non- motile, except few isolate in each developmental stage i.e. BL1B and BL1E in first instar larvae, BL3E, BL3F and $\mathrm{BL} 3 \mathrm{G}$ in third instar larvae, BP2, BP3 and BP6 in pupa, BM1 and BM4 in male adult flies and BF2 and BF4 in female adult flies were motile. On the basis of growth in broth, all the bacterial isolates of different stages have sediment growth while only bacterial isolate BM5 showed pellical formation in broth medium.

\section{Biochemical characterization}

In first instar larvae, Isolate BL1A and BL1C gave a positive reaction for citrate, VP, Indole, catalase and carbohydrate fermentation whereas, a negative reaction for MR, oxidase and TSI test. However, isolate BL1D have similar results for all the biochemical tests except indole negative. Isolate BL1B was citrate, catalase, oxidase and D-glucose positive while MR, VP, Indole, TSI, and gas production in glucose medium negative. A positive reaction for catalase, VP and D-glucose was observed for isolate BL1E and it was negative for MR, Indole and gas production in glucose medium while doubtful for oxidase, citrate and TSI tests. BL1F gave a positive reaction for citrate, MR, Indole, catalase and D-glucose whereas, a negative reaction for VP, oxidase and TSI test. The only cocci isolate BL1G gave positive reaction for VP, D-glucose and few other carbohydrates whereas, a negative reaction for citrate, Indole, catalase, oxidase and TSI test (Table 2).

In third instar larvae, BL3A isolate showed positive reaction for citrate, VP, catalase and D-glucose whereas, a negative reaction for MR, indole, oxidase and TSI test. Isolate BL3D and BL3I gave a positive reaction for citrate, VP, indole, catalase and carbohydrate fermentation whereas, a negative reaction for MR, oxidase and TSI test. However, isolate BL3C have similar results for all the biochemical tests except indole negative. A positive reaction for catalase, VP and Dglucose was observed for isolate BL3B and it was negative for $\mathrm{MR}$, indole and gas production in glucose medium while doubtful for oxidase, citrate and TSI tests. BL3E gave a positive reaction for citrate, MR, indole, catalase and D-glucose whereas, a negative reaction for VP, oxidase and TSI test. Isolate BL3F were citrate, catalase, oxidase and Dglucose positive while MR, VP, indole, TSI, and gas production in glucose medium negative. Isolate BL3G gave a positive reaction for citrate, MR, catalase and carbohydrate fermentation whereas, a negative reaction for, VP, Indole, oxidase and TSI test. Lastly the isolate BL3H have similar results as BL1G isolated from first instar larvae (Table 2).

In pupal stage, Isolate BP1 and BP7 gave a positive reaction for citrate, $\mathrm{VP}$, indole, catalase and carbohydrate fermentation whereas, a negative reaction for MR, oxidase and TSI test. However, isolate BP5 have similar results for all the biochemical tests except indole negative. The isolate BP2, BP4 and BP6 gave similar results for different biochemical tests as BL3F, BL3G and BL3E isolated from third instar larvae, respectively. Finally, BP3 gave a positive reaction for citrate, MR, Indole, catalase and D-glucose whereas, a negative reaction for VP, oxidase and TSI test (Table 2).

In adult stage, Bacterial isolates BM2 and BM6 (isolated from male adult flies) and BF1, BF3 and BF6 (isolated from female adult flies) gave a positive reaction for citrate, VP, Indole, catalase and carbohydrate fermentation whereas, a negative reaction for MR, oxidase and TSI test. However, isolate BM3 of male adult flies and BF5 of male 
adult flies have similar results as above isolates for all the biochemical tests except indole negative. The isolate BM1 (isolated from male adult flies) and BF4 (isolated from female adult flies) gave similar results for different biochemical tests as BP2 isolated from pupal stage. Isolate BM4 of male adult flies and BF2 of male adult flies have similar results for different biochemical tests. Finally, BM5 gave a positive reaction for catalase, Dglucose and sucrose whereas, a negative reaction for citrate, MR, Indole, VP, oxidase and TSI test were observed (Table 2).

\section{Identification of bacterial isolates associated with the developmental stage of the peach fruit fly, Bactrocera zonata}

The bacterial community associated with the developmental stage of the peach fruit fly isolated by culture-dependent technique were morphologically and biochemically characterized and belongs to various genera different family. The total 35 different bacterial colonies on the basis of colony morphology were screened and out of which, thirteen different bacterial species belonging to eleven genera (seven families) were identified from the developmental stage (first Instar larvae, third Instar larvae, pupa, male and female adults) of Bactrocera zonata (Table 3). The bacteria species viz., Klebsiella pneumonia, Klebsiella oxytoca, Enterobacter cloacae, Enterobacter sp., Providencia sp., Pantoea sp., Citrobacter freundii, Pseudomonas sp., Enterococcus sp., Ochrobactrum sp., Bacillus sp., Microbacterium sp., and Rhodococcus sp. were identified to be associated with different life stages. Out of total bacterial isolates, seven bacterial species from first instar larvae, nine from third instar larvae, seven from pupae and six each from male and female adult flies were identified. Genera Klebsiella, Enterobacter and Pseudomonas were found in all the development stages.
To the best of our knowledge, this study is the first of its kind to explore the cultivable bacterial community in the different life stages (larvae, pupae, male and female adults) of B. zonata by conventional method. The gut of tephritid fruit flies in general (Behar et al., 2009; Lloyd et al., 1986; Wang et al., 2011) and $B$. zonata in particular (Reddy et al., 2014; Naaz et al., 2016; Naaz et al., 2020) is a storehouse of bacterial community. In the present study, 35 different bacterial colonies were designated to thirteen different bacterial species. The bacteria species viz., Klebsiella pneumonia, Klebsiella oxytoca, Enterobacter cloacae, Enterobacter sp., Providencia sp., Pantoea sp., Citrobacter freundii, Pseudomonas sp., Enterococcus sp., Ochrobactrum sp., Bacillus sp., Microbacterium sp., and Rhodococcus sp. were identified to be associated with different life stages. Enterobacteriaceae was found to be the predominant family in all the developmental stages. Moreover, Enterobacteriaceae have frequently been identified as the dominant species in the gut of several other tephritids, such as Dacus (Drew and Lloyd 1987), Bactrocera (Capuzzo et al., 2005; Prabhakar et al., 2009; Shi et al., 2012; Wang et al., 2011, 2013), Anastrepha (Kuzina et al., 2001) and Ceratitis (Behar et al., 2008). These findings show that such bacteria are widespread in tephritids, suggesting a stable association with these fruit flies (Jang and Nishijima 1990; Lauzon et al., 2009; Wang et al., 2011).

The bacterial species Enterobacter sp., $K$. oxytoca, K. pneumoniae and Pseudomonas sp., were common across all the developmental stages of $B$. zonata suggest the possibility of vertical transmission of these bacterial communities. Vertical transition is common for some of the bacterial communities in tephritid flies (Andongma et al., 2015; Lauzon et al., 2009; Naaz et al., 2020). 
Table.1 Isolation of gut bacteria from different development stages of Bactrocera zonata

\begin{tabular}{|l|c|l|c|l|}
\hline $\begin{array}{l}\text { Development stages of } \boldsymbol{B} \\
\text { zonata isolates used for } \\
\text { bacterial isolation }\end{array}$ & \multicolumn{4}{|c|}{ Culture media used } \\
\cline { 2 - 5 } & $\begin{array}{l}\text { Peptone Yeast Extract Agar (PYEA) } \\
\text { Bacterial } \\
\text { colonies } \\
\text { isolated }\end{array}$ & Bacterial isolate number & $\begin{array}{l}\text { Bacterial } \\
\text { colonies } \\
\text { isolated }\end{array}$ & \multicolumn{1}{|c|}{ Bacterial isolate number } \\
\hline First Instar larvae & 5 & BL1A, BL1B, BL1C, BL1D, BL1E & 2 & BL1F, BL1G \\
\hline Third Instar larvae & 7 & $\begin{array}{l}\text { BL3A, BL3B, BL3C, BL3D, BL3E, } \\
\text { BL3F, BL3I }\end{array}$ & 2 & BL3G, BL3H \\
\hline Pupa & 6 & BP1, BP2, BP3, BP4, BP5, BP7 & 1 & BP6 \\
\hline Adult Male & 5 & BM1, BM3, BM4, BM5, BM6 & 1 & BM2 \\
\hline Adult Female & 5 & BF1, BF2, BF3, BF4, BF5 & 1 & BF6 \\
\hline
\end{tabular}

Table.2 Morphological and biochemical characteristics of bacteria associated with the developmental stages of the peach fruit fly, Bactrocera zonata

\begin{tabular}{|c|c|c|c|c|c|c|c|c|c|c|c|c|c|}
\hline \multirow{2}{*}{ 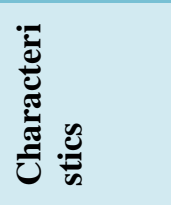 } & \multicolumn{13}{|c|}{ Bacterial isolates } \\
\hline & 톨 लै & 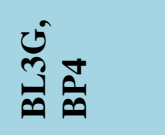 & 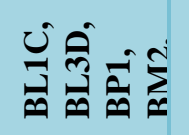 & $\frac{b}{\infty}$ & 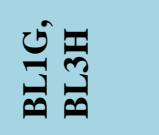 & 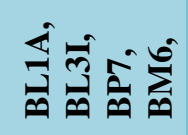 & 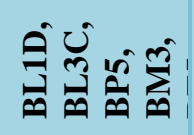 & 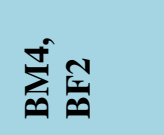 & $\tilde{n}$ & $\stackrel{\pi}{3}$ & 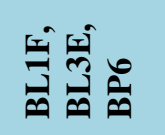 & 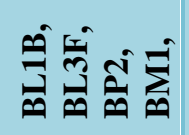 & $\sum_{\infty}^{n}$ \\
\hline \multicolumn{14}{|c|}{ Morphological } \\
\hline Shape & Rod shape & Rod shape & $\begin{array}{l}\text { Rod } \\
\text { shape }\end{array}$ & $\begin{array}{l}\text { Rod } \\
\text { shape }\end{array}$ & $\begin{array}{l}\text { Cocci } \\
\text { shape }\end{array}$ & Rod shape & Rod shape & $\begin{array}{l}\text { Rod } \\
\text { shape }\end{array}$ & $\begin{array}{l}\text { Rod } \\
\text { shape }\end{array}$ & $\begin{array}{l}\text { Rod } \\
\text { shape }\end{array}$ & $\begin{array}{l}\text { Rod } \\
\text { shape }\end{array}$ & Rod shape & $\begin{array}{l}\text { Rod- } \\
\text { coccus } \\
\text { shape }\end{array}$ \\
\hline Motility & - & + & - & - & - & - & - & + & + & + & + & + & - \\
\hline $\begin{array}{l}\text { Gram's } \\
\text { reaction }\end{array}$ & + & - & - & - & + & - & - & + & - & - & - & - & + \\
\hline $\begin{array}{l}\text { Colonies } \\
\text { Colour }\end{array}$ & $\begin{array}{l}\text { Creamy } \\
\text { white }\end{array}$ & $\begin{array}{l}\text { Opaque, } \\
\text { mucoid }\end{array}$ & $\begin{array}{l}\text { White \& } \\
\text { opaque }\end{array}$ & $\begin{array}{l}\text { White \& } \\
\text { opaque }\end{array}$ & White & White & $\begin{array}{l}\text { Creamy } \\
\text { White }\end{array}$ & Yellow & White & Yellow & Dull grey & Light & Orange \\
\hline $\begin{array}{l}\text { Growth in } \\
\text { broth } \\
\text { medium }\end{array}$ & Sediment & Sediment & Sediment & Sediment & Sediment & Sediment & Sediment & Sediment & Sediment & Sediment & Sediment & Sediment & $\begin{array}{l}\text { Pellical } \\
\text { formation }\end{array}$ \\
\hline
\end{tabular}




\begin{tabular}{|c|c|c|c|c|c|c|c|c|c|c|c|c|c|}
\hline \multicolumn{14}{|c|}{ Biochemical } \\
\hline Citrate test & + & + & + & + & - & + & + & + & + & + & + & + & - \\
\hline $\begin{array}{l}\text { Methyl red } \\
\text { test }\end{array}$ & - & + & - & - & \pm & - & - & - & - & - & + & - & - \\
\hline V.P test & + & - & + & + & + & + & + & - & - & + & - & - & - \\
\hline Indole test & - & - & + & + & - & + & - & - & - & - & + & - & - \\
\hline TSI test & \pm & & - & - & - & - & - & - & - & - & - & - & - \\
\hline Catalase test & + & + & + & + & - & + & + & + & + & + & + & + & + \\
\hline Oxidase test & \pm & - & - & - & - & - & - & - & + & - & - & + & - \\
\hline $\begin{array}{l}\text { Growth in } \\
10 \% \mathrm{NaCl}\end{array}$ & + & + & + & + & + & + & + & + & + & + & + & + & - \\
\hline \multicolumn{14}{|c|}{ Carbohydrate fermentation } \\
\hline D-Glucose & + & + & + & + & + & + & + & + & - & + & + & + & + \\
\hline $\begin{array}{l}\text { D- Glucose } \\
\text { (Gas } \\
\text { production) }\end{array}$ & - & - & + & + & - & + & + & - & - & - & - & - & - \\
\hline Sucrose & \pm & + & + & + & \pm & + & + & + & + & + & \pm & - & + \\
\hline Lactose & - & + & + & + & + & + & + & + & + & - & - & - & - \\
\hline Maltose & + & + & + & + & + & + & + & + & + & + & - & + & - \\
\hline Raffinose & + & \pm & + & + & - & + & + & - & - & - & - & \pm & - \\
\hline D-Mannose & + & + & + & + & + & + & + & + & + & + & + & - & - \\
\hline Trehalose & + & + & + & + & + & + & + & - & - & + & + & - & + \\
\hline Celliobiose & + & + & + & + & + & + & + & - & - & - & - & - & - \\
\hline D-Sorbitol & + & + & + & + & - & + & + & + & - & - & - & - & + \\
\hline Inositol & + & - & + & + & - & + & + & - & - & \pm & \pm & - & + \\
\hline D-Xylose & + & + & + & + & - & + & + & + & - & + & \pm & - & \pm \\
\hline Identified as & $\begin{array}{l}\text { Bacillus } \\
\text { sp. }\end{array}$ & $\begin{array}{l}\text { Citrobacter } \\
\text { freundii }\end{array}$ & $\begin{array}{l}\text { Enteroba } \\
\text { cter sp. }\end{array}$ & $\begin{array}{l}\text { Enteroba } \\
\text { cter } \\
\text { cloacae }\end{array}$ & $\begin{array}{l}\text { Enteroco } \\
\text { ccus sp. }\end{array}$ & $\begin{array}{l}\text { Klebsiella } \\
\text { oxytoca }\end{array}$ & $\begin{array}{l}\text { Klebsiella } \\
\text { pneumonia }\end{array}$ & $\begin{array}{l}\text { Microbac } \\
\text { terium sp. }\end{array}$ & $\begin{array}{l}\text { Ochroba } \\
\text { ctrum sp. }\end{array}$ & $\begin{array}{l}\text { Pantoea } \\
\text { sp. }\end{array}$ & $\begin{array}{l}\text { Providen } \\
\text { cia sp. }\end{array}$ & $\begin{array}{l}\text { Pseudomo } \\
\text { nas sp. }\end{array}$ & $\begin{array}{l}\text { Rhodococ } \\
\text { cus sp. }\end{array}$ \\
\hline
\end{tabular}


Table.3 Identified cultured bacteria at different development stages of Bactrocera zonata

\begin{tabular}{|c|c|c|c|c|c|c|c|}
\hline SI No. & Family & Bacteria & $\begin{array}{l}\text { First } \\
\text { Instar } \\
\text { larvae }\end{array}$ & $\begin{array}{l}\text { Third } \\
\text { Instar } \\
\text { larvae }\end{array}$ & Pupa & $\begin{array}{l}\text { Adult } \\
\text { Male }\end{array}$ & $\begin{array}{l}\text { Adult } \\
\text { Female }\end{array}$ \\
\hline 1. & Enterobacteriaceae & Klebsiella pneumonia & + & + & + & + & + \\
\hline 2. & Enterobacteriaceae & Enterobacter cloacae & - & - & - & - & + \\
\hline 3. & Enterobacteriaceae & Enterobacter sp. & + & + & + & + & + \\
\hline 4. & Enterobacteriaceae & Klebsiella oxytoca & + & + & + & + & + \\
\hline 5. & Enterobacteriaceae & Providencia sp. & + & + & + & - & - \\
\hline 6. & Pseudomonadaceae & Pseudomonas sp. & + & + & + & + & + \\
\hline 7. & Enterobacteriaceae & Citrobacter freundii & - & + & + & - & - \\
\hline 8. & Microbacteriacea & Microbacterium sp. & - & - & - & + & + \\
\hline 9. & Nocardiaceae & Rhodococcus sp. & - & - & - & + & - \\
\hline 10. & Enterococcaceae & Enterococcus sp. & + & + & - & - & - \\
\hline 11. & Brucellaceae & Ochrobactrum sp. & - & - & + & - & - \\
\hline 12. & Bacillaceae & Bacillus sp. & + & + & - & - & - \\
\hline \multirow[t]{2}{*}{13.} & Enterobacteriaceae & Pantoea sp. & - & + & - & - & - \\
\hline & & $\begin{array}{l}\text { Total bacterial } \\
\text { species }\end{array}$ & 7 & 9 & 7 & 6 & 6 \\
\hline
\end{tabular}


Recently, It has been also postulated that gut enterobacteria are dispersed into the female reproductive system, where they are subsequently transferred to the eggs, then to fruit during oviposition and finally passed to the fly offspring (Behar et al., 2008; Shi et al., 2012). Among all the common bacterial species across developmental stages, Pseudomonas sp. was not reported earlier to be associated with $B$. zonata. However, genus Pseudomonas have been reported from many insect species including fruit flies such as Bactrocera dorsalis, Zeugodacus tau (Brinkmann et al., 2008; Sood and Nath, 2002; Prabhakar et al., 2013, Noman et al., 2020).

Earlier, $K$. oxytoca, $K$. pneumonia, Enterobacter cloacae, Enterobacter sp., Bacillus sp., Microbacterium sp., and Rhodococcus sp. were also reported from the gut of B. zonata (Reddy et al., 2014; Naaz et al., 2016) whereas, Citrobacter freundii, Providencia sp., Pantoea sp., Pseudomonas sp., Enterococcus sp., and Ochrobactrum sp. were newly added in the list of bacterial community associated with the $B$. zonata. However, genera Citrobacter and Providencia were identified from four Bactrocera species (Lloyd et al., 1986) and B. dorsalis (Gujjar et $a l$. , 2017). The bacterial species of genus Pantoea, is a free-living diazotrophic bacterium of family Enterobacteriaceae and was consistently reported from the different organs and stages of Zeugodacus cucurbitae and Z.tau (Sood and Nath 2002; Prabhakar et al., 2009). Ochrobactrum sp. have been reported from many insect species including fruit flies such as $B$. dorsalis and $Z$. tau (Brinkmann et al., 2008; Sood and Nath, 2002; Prabhakar et al., 2013, Noman et al., 2020). Thus the present findings get substantial support from the observations of other workers, who consistently observed the association of phylum, Proteobacteria with different organs and developmental stages of other Bactrocera species (Sood and Nath, 2002; Prabhakar et al., 2013, Gujjar et al., 2017, Noman et al., 2020) including B. zonata (Reddy et al., 2014; Naaz et al., 2016; Naaz et al., 2020).

The present finding added a few more genera to the list of bacterial diversity of the $B$. zonata, but a vast range of gut bacterial diversity exists in the $B$. zonata system is still unkown. Therefore, an extensive study to explore the gut bacterial diversity across all the developmental stages of the fly and to understand the host behavior in relation to gut bacterial community are needed using both culture-dependent and -independent techniques (with large number of replicates). However, our study significantly supplements to the available information on the cultivable bacterial diversity associated with the developmental stages of B. zonata.

\section{References}

Aharon, Y., Pasternak, Z., Ben Yosef, M., Behar, A., Lauzon, C., Yuval, B., et al., (2013) Phylogenetic, metabolic, and taxonomic diversities shape Mediterranean fruit fly microbiotas during ontogeny. Appl Environ Microb 79(1): 303-313. https://doi.org/10.11 28/AEM.02761-12

Andongma, A.A., Wan, L., Dong, Y-C., Li, P., Desneux, N., White, J.A. and Niu, C.Y. (2015) Pyrosequencing reveals a shift in symbiotic bacteria populations across life stages of Bactrocera dorsalis. Sci Rep, 5: 9470.

Behar, A., Ben-Yosef, M., Lauzon, C.R., Yuval, B. and Jurkevich, E. (2009). Structure and function of the bacterial community associated with the Mediterranean fruit fly. In K. Bourtzis and T. Miller (Eds.), Insect symbiosis (pp. 251-271). Boca Raton: CRC.

Behar, A., Jurkevitch, E., and Yuval, B. (2008). Bringing back the fruit into fruit fly- 
bacteria interactions. Molecular Ecology, 17, 1375-1386.

Brinkmann, N., Martens, R., and Tebbe, C.C. (2008). Origin and diversity of metabolically active gut bacteria from laboratory-bred larvae of Manduca sexta (Sphingidae: Lepidoptera: Insecta). Applied and Environmental Microbiology, 74, 7189-7196.

CABI/EPPO (2013) Bactrocera zonata. [Distribution map]. Distribution Maps of Plant Pests, No. December, 3rd revision, CABI, Wallingford, UK, Map 125.

Capuzzo, C., Firrao, G., Mazzon, L., Squartini, A., and Girolami, V. (2005) "Candidatus Erwinia dacicola", a co-evolved symbiotic bacterium of the olive fly, Bactrocera oleae (Gmelin). Int J Syst Evol Microbiol 55: 1641-1647.

Choudhary, J.S., Mali, S.S., Naaz, N., Mukherjee, D., Maonaro, Das, B., Singh, A.K., Rao, M.S. and Bhatt, B.P. (2020) Predicting the population growth potential of Bactrocera zonata (Saunders) (Diptera: Tephritidae) using temperature development growth models and their validation in fluctuating temperature condition. Phytoparasitica 48: 1-13. https://doi.org/10.1007/s12600-01900777-4

Choudhary, J.S., Naaz, N., Lemtur, M., Das, B., Singh, A.K., Bhatt, B.P., and Prabhakar, C.S. (2018) Genetic analysis of Bactrocera zonata (Diptera: Tephritidae) populations from India based on coxl and nadl gene sequences. Mitochondrial DNA Part A 29 (5): 727-736.

Choudhary, J.S., Naaz, N., Prabhakar, C.S., Srinivasa Rao, M., and Das, B. (2015). The mitochondrial genome of the peach fruitfly, Bactrocera zonata (Saunders) (Diptera: Tephritidae): complete DNA sequence, genome organization, and phylogenetic analysis with other tephritids using next generation DNA sequencing. Gene, 569, 191-202.

Dale, C., and Moran, N.A. (2006). Molecular interactions between bacterial symbionts and their hosts. Cell, 126, 453-465.
Dillon, R.J., and Dillon, V.M. (2004). The gut bacteria of insects: nonpathogenic interactions. Annual Review of Entomology, 49, 71-92.

Douglas, A.E. (2015). Multiorganismal Insects: Diversity and Function of Resident Microorganisms. Annu Rev Entomol 60:17-34.

Drew, R.A.I., and Lloyd, A.C. (1987). Relationship of fruit flies (Diptera: Tephritidae) and their bacteria to host plants. Annals of the Entomological Society of America, 80, 629-636.

Duyck, P.F., Sterlin, J.F., and Quilici, S. (2004). Survival and development of different life stages of Bactrocera zonata (Diptera: Tephritidae) reared at five constant temperatures compared to other fruit fly species. Bull Entomol Res 94:89-93.

Engel, P., and Moran, N.A. (2013). The gut microbiota of insects-diversity in structure and function. FEMS Microbiol Rev 37:699-735. https://doi.org/10.111 1/1574-6976.12025 PMID: 23692388

Ezenwa, V.O., Gerardo, N.M., Inouye, D.W., Medina, M., and Xavier, J.B. (2012). Microbiology: animal behaviour and the microbiome. Science 338:198-99

Feldhaar, H. (2011). Bacterial symbionts as mediators of ecologically important traits of insect hosts. Ecol Entomol 36(5):533543. https://doi.org/10.1111/j.1365311.2011.01318.x

Ferrari, J., Scarborough, C.L., and Godfray, H.C.J. (2007). Genetic variation in the effect of a facultative symbiont on hostplant use by pea aphids. Oecologia 153(2):323-329. https://doi.org/10.1007/s00442-007-07302 PMID: 17415589

Gujjar, N.R., Govindan, S., Verghese, A., Subramaniam, S., and More, R. (2017). Diversity of the cultivable gut bacterial communities associated with the fruit flies Bactrocera dorsalis and Bactrocera cucurbitae (Diptera: Tephritidae). Phytoparasitica 45, 453-460. doi: 10.1007/s12600-017-0604-z

Hammer, T.J., and Bowers, M.D. (2015) Gut 
microbes may facilitate insect herbivory of chemically defended plants. Oecologia 179(1):

$1-14$.

https://doi.org/10.1007/s00442-015-3327-

1 PMID: 25936531

Holt, J.G., Krieg, N.R., Sneath, P.H.A., Staley, J.T., and Williams, S.T. (2000). Bergey's manual of determinative bacteriology (pp. 175-533). New York: LIPPNCOTT Williams and Wilkins

Hosokawa, T., Kikuchi, Y., Shimada, M., and Fukatsu, T. (2017) Obligate symbiont involved in pest status of host insect. Proc R Soc Lond [Biol] 274: 1979-1984.

Jang, E.B., and Nishijima, K.A. (1990). Identification and attractancy of bacteria associated with Dacus dorsalis (Diptera: Tephritidae). Environmental Entomology, 19, 1726-1731.

Kapoor, V.C. (1993). Indian fruit flies (Insecta: Diptera: Tephritidae). International Sciences Publisher, New York, pp 228

Kuzina, L.V., Peloquin, J.J., Vacek, D.C., and Miller, T.A. (2001). Isolation and identification of bacteria associated with adult laboratory Mexican fruit flies, Anastrepha ludens (Diptera: Tephritidae). Current Microbiology, 42, 290-294.

Lauzon, C., McCombs, S., Potter, S., and Peabody, N. (2009). Establishment and vertical passage of Enterobacter (Pantoea) agglomerans and Klebsiella pneumonia through all life stages of the Mediterranean fruit fly (Diptera: Tephritidae). Ann Entomol Soc Am 102: 85-95.

Liu, L.J., Martinez-Sañudo, I., Mazzon, L., Prabhakar, C.S., Girolami, V., Deng, Y.L., Dail, Y. and Li, Z.H. (2016) Bacterial communities associated with invasive populations of Bactrocera dorsalis (Diptera: Tephritidae) in China. Bulletin of Entomological Research, 106, 718-728.

Lloyd, A.C., Drew, R.A.I., Teakle, D.S., and Hayward, A.C. (1986). Bacteria associated with some Dacus species (Diptera: Tephritidae) and their host fruits in Queensland. Australian Journal of
Biological Sciences, 39, 361-368.

Malacrinò, A., Campolo, O., Medina, R.F., and Palmeri, V. (2018). Instar- and hostassociated differentiation of bacterial communities in the Mediterranean fruit fly Ceratitis capitata. PLoS ONE 13(3): e0194131. https://doi.org/10.1371/ journal.pone. 0194131

Medina, R.F., Nachappa, P., and Tamborindeguy, C. (2011) Differences in bacterial diversity of host-associated populations of Phylloxer anotabilis Pergande (Hemiptera: Phylloxeridae) in pecan and water hickory. J Evol Biol 24(4):761-71. https://doi.org/10.111 1/j.1420-9101.2010.02215.x PMID: 21261774

Naaz, N., Choudhary, J.S., Choudhary, A., Dutta, A., and Das, B. (2020) Developmental stage- associated microbiota profile of the peach fruit fly, Bactrocera zonata (Diptera: Tephritidae) and their functional prediction using 16S rRNA gene metabarcoding sequencing. 3 Biotech, 10:390. https://doi.org/10.1007/s13205-02002381-4

Naaz, N., Choudhary, J.S., Prabhakar, C.S., Moanaro, and Maurya, S. (2016) Identification and evaluation of cultivable gut bacteria associated with peach fruit fly, Bactrocera zonata (Diptera: Tephritidae). Phytoparasitica 44:165-176.

Noman, M.S., Shi, G., Liu, L., and Li, Z.H. (2020) The diversity of bacteria in different life stages and their impact on the development and reproduction of Zeugodacus tau (Diptera: Tephritidae). Insect Sci. 00, 1-14.

Oliver, K.M., Russell, J.A., Moran, N.A., and Hunter, M.S. (2003). Facultative bacterial symbionts in aphids confer resistance to parasitic wasps. Proc Natl Acad Sci 100(4):1803-1807. https://doi.org/10.1073/pnas.0335320100 PMID: 12563031

Petri, L. (1909). Ricerche Sopra i Batteri Intestinali della Mosca Olearia. Roma: Memorie della Regia Stazione di 
Patologia Vegetale di Roma.

Prabhakar, C.S., Sood, P., Kapoor, V., Kanwar, S.S., Mehta, P.K., and Sharma, P.N. (2009) Molecular and biochemical characterization of three bacterial symbionts of fruit fly, Bactrocera tau (Tephritidae: Diptera). J Gen Appl Microbiol 55: 479-487.

Prabhakar, C.S., Sood, P., Kanwar, S.S., Sharma, P.N., Kumar, A. and Mehta, P.K. (2013) Isolation and characterization of gut bacteria of fruit fly, Bactrocera tau (Walker). Phytoparasitica, 41, 193-201.

Reddy, K., Sharma, K., and Singh, S. (2014). Attractancy potential of culturable bacteria from the gut of peach fruit fly, Bactrocera zonata (Saunders). Phytoparasitica. doi:10.1007/s12600-0140410-9.

Russell, J.A., and Moran, N.A. (2006). Costs and benefits of symbiont infection in aphids: variation among symbionts and across temperatures. Proc R Soc Lond [Biol] 273(1586): 603-610. https://doi.org/10.1098/rspb.2005.3348 PMID: 16537132.

Shi, Z., Wang, L., and Zhang, H. (2012). Low diversity bacterial community and the trapping activity of metabolites from cultivable bacteria species in the female reproductive system of the oriental fruit fly, Bactrocera dorsalis Hendel (Diptera: Tephritidae). International Journal of Molecular Sciences, 13, 6266-6278.
Sood, P., and Nath, A. (2002). Bacteria associated with Bactrocera sp. (Diptera: Tephritidae) - isolation and identification. Pest Management and Economic Zoology, 10, 1-9.

Wagner, S.M., Martinez, A.J., Ruan, Y-M., Kim, K.L., Lenhart, P.A., Dehnel, A.C. et al., (2015) Facultative endosymbionts mediate dietary breadth in a polyphagous herbivore. Funct Ecol 29(11): 1402-1410. https://doi.org/10.111 1/1365-2435.12459

Wang, H., Jin, L., and Zhang, H. (2011). Comparison of the diversity of the bacterial communities in the intestinal tract of adult Bactrocera dorsalis fromthree different populations. Journal of Applied Microbiology, 110, 13901401.

Wang, H., Jin, L., Peng, T., Zhang,H., Chen, Q., and Hua, Y. (2013). Identification of cultivable bacteria in the intestinal tract of Bactrocera dorsalis from three different populations and determination of their attractive potential. Pest Management Science.

Wingfield, M.J., Garnas, J.R., Hajek, A., Hurley, B.P., de Beer, Z.W., and Taerum, S.J. (2016) Novel and co-evolved associations between insects and microorganisms as drivers of forest pestilence. Biol Invasions 18:1045-1056.

\section{How to cite this article:}

Naiyar Naaz, Jaipal S. Choudhary, Ashok Choudhary and Abhijit Dutta. 2020. Morphological and Biochemical Characterization of Bacteria Associated with the Developmental Stage of the Peach Fruit Fly, Bactrocera zonata (Diptera: Tephritidae). Int.J.Curr.Microbiol.App.Sci. 9(10): 1349-1360. doi: https://doi.org/10.20546/ijcmas.2020.910.162 